\title{
Making Mechanization Accessible to Smallholder Farmers in Sub-Saharan Africa
}

\author{
Brian Sims ${ }^{1, *}$ and Josef Kienzle ${ }^{2}$ \\ 1 Agricultural Engineer, Engineering for Development, 3 Bourneside, Bedford MK41 7EG, UK \\ 2 Agricultural Engineer, Plant Production and Protection Division, Food and Agriculture Organization of the \\ United Nations (FAO), Viale delle Terme di Caracalla, Rome 00153, Italy; Josef.Kienzle@fao.org \\ * Correspondence: BrianGSims@aol.com; Tel.: +44-1234-271-699
}

Academic Editor: Yu-Pin Lin

Received: 29 January 2016; Accepted: 7 April 2016; Published: 19 April 2016

\begin{abstract}
This paper summarizes the deliberations at a meeting convened by the Bill \& Melinda Gates Foundation held in Beijing in October 2015. Farm power and mechanization are agricultural production inputs that will be essential to raise the labor and land productivity required if Sustainable Development Goals 1 and 2 (ending poverty and hunger) are to be achieved. The smallholder farm sector demand for mechanization needs to be raised to stimulate the product value chain and activate input supply (that is to raise farm productivity, stimulate value addition, and encourage private sector custom hire service provision). The sustainability of mechanization from a natural resource conservation point of view is discussed with reference to conservation agriculture principles. Mechanization appropriate for the smallholder sector covers the range of possible power sources human, draft animal and motorized. The key is to engage all the stakeholders in the supply chain and offer a range of suitable options from which the user can select. Sustainability of mechanization includes financial and social, as well as environmental factors. Local manufacturers should be supported where feasible as they can provide implements and machines adapted to local conditions-and better technical service and replacement part supply. The public sector role in providing access to mechanization should be restricted to promulgating enabling policies, building technical and business management skills and stimulating demand. The lessons to be learnt from Chinese experience in making mechanization available to smallholder farmers include subsidies, strong extension services, infrastructure development and a solid manufacturing sector that prioritizes the smallholder sector. The implications for sub-Saharan Africa appear to be that group ownership and custom hire service provision are the models to follow. Finally, the relevance of an African Center for Sustainable Agricultural Mechanization, on the model of CSAM in Beijing, is considered and recommended.
\end{abstract}

Keywords: essential agricultural input; value chains; demand creation; provision mechanisms; local manufacture; Chinese experience; center for sustainable mechanization

\section{Background}

From 18 to 21 October 2015, an international gathering of people involved in smallholder mechanization issues took place in Beijing, China; the meeting was convened by the Bill \& Melinda Gates Foundation. The Grand Challenges program of the Foundation engages innovators from around the world to solve the most pressing challenges in global health and development. The Beijing meeting included, amongst many crucial health themes, a track on accessible mechanization for smallholder farmers.

The emphasis of the meeting was on development for Africa and, in particular, three focus countries selected by the Foundation: Nigeria, Tanzania and Ghana. There was a strong representation 
from China to describe their country's strategy for smallholder mechanization, and its relevance for development in Africa. There were also important international delegations from the private sector farm machinery industry, from research and development (R\&D) organizations (especially the Consortium of International Agricultural Research Centers (CGIAR)) and United Nations (UN) institutions (Food and Agriculture Organization-FAO, and the Centre for Sustainable Agricultural Mechanization (CSAM) of the UN-Economic and Social Commission for Asia and the Pacific (ESCAP)), and African national organizations, amongst many others. The wide-ranging discussions, presentations and panel sessions fully occupied the three days of the meeting. This paper summarizes the main issues raised and points the way to concrete actions that can make the essential farm power and mechanization input more readily accessible to smallholder farmers in the African continent.

\section{Mechanization, an Essential Input}

\subsection{Sustainable Development Goals}

In September 2015 the UN adopted the 17 sustainable development goals (SDGs) that will replace the Millennium Development Goals [1]. These new goals will frame the development agendas and political policies of member states over the next fifteen years. There are 17 goals in total and of these, SDG1 (Ending poverty) and SDG2 (Zero hunger) are the most compellingly important for improving the livelihoods of smallholder farmers. SDG12 (Ensuring sustainable consumption and production patterns) also fits in well with the pressing need for sustainable crop production intensification (SCPI), which will protect natural resources while producing food for the world's growing population. Achieving SCPI will require a sharp improvement in labor and land productivity in the smallholder farming sector which produces $80 \%$ of the food in developing countries. This will mean improved access to essential crop production inputs including quality seed, fertilizer and irrigation water, but also will necessitate increased access to farm power and machinery.

\subsection{Farm Power and Mechanization-An Essential Input}

The topic of agricultural mechanization for smallholder farmers in sub-Saharan Africa (SSA) has, for long, been a neglected one. It is now clear that mechanization is an essential input to raise labor and land productivity and reduce drudgery. Mechanization can also be used to add value to primary products and so produce employment and income potential along the value chain [2].

As the global population continues to increase, the population of rural areas is decreasing as the young and fit migrate to urban centers. Today $50 \%$ of the population in developing countries lives in the rural sector and this will fall to $30 \%$ by 2050 [3].

Quantitative data on the specific impacts of mechanization as an essential production input on smallholder farming systems in SSA are, by nature, site-specific and so generalizations are not always easy to make; but some authors have focused on the issue both in SSA and in other regions of the world (particularly Asia). Agarwal [4] reporting on the situation in south Asia found that disaggregating the production labor tasks per type of crop, type of farm and location of farm can provide a clearer picture of labor productivity per task and found that overall productivity tends to rise with mechanization. Clare Bishop-Sambrook [5] reviewed the mechanization inputs available to 14 communities in seven countries in SSA. She concluded that households typically cultivate 1-2 ha per year, draft animal power (DAP) hirers cultivate 2 ha, households owning DAP cultivate 3-4 ha, tractor hirers cultivate about 8 ha and households owning tractors cultivate more than 20 ha.

Van Eerdewijk and Danielsen [6] look specifically at gender issues associated with the demand for farm power. They indicate that the farming activities that women consider as contributing to their labor burden include: weeding, tillage and land preparation, post-harvest management and transport of agricultural produce. Women consider all tasks where they have to rely solely on their own muscle power (such as weeding, fodder collection or transport of produce carried on their own backs) or 
hand-tools (e.g., for threshing and grinding) as highly labor-intensive. Across sites in Kenya and Ethiopia, hiring labor and the use of DAP are the most common ways to reduce labor burdens.

As early as 1975 Giles [7] had shown that agricultural productivity is positively correlated with farm power throughout the world and including developing countries. Reid [8] gives the view from the USA by tracing agricultural technology development (mechanization) from the mid-1800s to the present in terms of factor productivity and finds four main aspects of this development: improved labor efficiency, improved production input efficiency, improved timeliness of operations and the enabling of more sustainable production systems to be implemented. Singh [9], focusing on the Indian situation where manual, animal and tractor-powered crop production systems are all practiced, estimates that farm power significantly contributes to increased yields. He reveals that regions having higher cereal crop yields have also adopted higher levels of mechanization. This yield increase is primarily a result of improved timeliness of operations. Verma [10] concurs that mechanization has a positive impact on timeliness (which can result in yield increases as high as 70\%) and adds that this can also result in increased cropping intensities (of around 150\%).

In terms of agricultural production Faleye et al. [11] report that the use of power tillers on small-scale farms in Nigeria resulted in yield increases of up to $70 \%$ in some crops. The FAO and World Bank [12] reporting on agricultural production in the Kyrgyz republic show that, as a consequence of the lack of mechanization, inadequate and delayed seedbed preparation, high costs of land preparation and harvesting, increased harvest losses and loss of fodder all affect aggregate agricultural production output.

FAO [13] suggests that mechanization options using animal- and engine-powered technologies will only be viable in SSA if they contribute in the following ways:

- Increasing labor productivity;

- Expanding the area under cultivation;

- Increasing land productivity (especially through improved timeliness of operations);

- Improving profits and reducing costs; and

- Reducing drudgery.

With regard to the importance of timeliness of agricultural operations, many studies have shown the yield penalty incurred by delayed sowing (and weeding). This can be as high as $1 \% /$ day of delay for many crops (e.g., Baudron et al. [14]).

FAO [13] cites Barton et al. [15], and gives a comparison of labor costs and returns with respect to weeding by hand and DAP (Table 1).

Table 1. Labor costs and returns with respect to weeding in NE Uganda.

\begin{tabular}{ccccc}
\hline \multirow{2}{*}{ Aspects of weeding costs } & \multicolumn{2}{c}{ Sorghum } & \multicolumn{2}{c}{ Groundnuts } \\
\cline { 2 - 5 } & DAP Weeding & Hand Weeding & DAP Weeding & Hand Weeding \\
\hline Weeding (h/ha) & 34.7 & 157.8 & 31.8 & 73.2 \\
Cost of weeding (USD) & 6.12 & 27.85 & 8.07 & 18.07 \\
Return per day of weeding labor (USD) & 11.40 & 2.19 & 135.78 & 18.42 \\
Weeding as \% of total costs (\%) & 13.2 & 51.3 & 7.7 & 21.5 \\
\hline
\end{tabular}

Mrema et al. [16] give convincing evidence that a lack of focus on improving access to mechanization has meant that SSA farmers now lag well behind their counterparts in Asia and Latin America, despite being on a par with them in the 1960s. They conclude that, without a commitment to mechanization the prospects for African farmers remain bleak. These issues and strategies to enable mechanization to be made more available to farmers in SSA were discussed at high-level in an FAO-sponsored meeting in 2011 [17] where it was concluded for improved profitability, wider use of machines and power sources along the value chain should be encouraged and supported. 
As for the need for mechanization along the value chain, according to the FAO, the key to poverty reduction is accelerated economic growth and employment generation [18]. The establishment of viable agro-processing enterprises in rural areas can be important for creating employment and income and, thereby, enhancing the demand for farm produce. In rural areas, economic growth will, in most instances, be led by the growth of commercial agri-food systems that are run efficiently and are responsive to evolving market demands. The efficiency of post-harvest handling, processing and marketing operations is a major determinant of the prices paid by urban and rural poor, and is an important factor in ensuring household food security. Agro-enterprise development has the potential to provide employment for the rural poor in off-farm activities such as the handling, packaging, processing, transporting and marketing of food and agricultural produce.

A value chain approach to improving production methods from producer to sale to the consumer usually gives positive results. Yaregal [19] gives details of a value chain approach to rice production, processing, marketing and policy making in Ethiopia. When all stakeholders work together according to an agreed development plan, then an improved outcome is almost assured. A major component of this approach is facilitating processors to gain access to credit services to purchase new (and better) equipment for the production of higher quality (and value) rice. There is also a focus on improved technologies for rice production, which have resulted in yield increases in the region of 20\%. FAO [20] in a comparative study of the situation in Kenya, Brazil and Pakistan found that mechanization can be an effective leverage point for agri-food value chain development so long as there is a functional equipment supply chain. More specifically FAO [2] in an SSA-specific study shows that mechanization can have positive impacts on agri-food value chain development at harvest, post-harvest, processing and retailing stages in particular, which go beyond the conventional focus on improved agricultural production practices alone. Hilmi [21] finds in Iran, Tanzania and The Gambia how mechanized hire services can provide positive benefits and impacts to the development of agri-food value chains.

Perhaps the most eloquent testimony for the need for increased access to farm power comes from smallholder farmers themselves. Qualitative, rather than quantified, quotes such as: "Animal traction makes the difference between night and day"; and: "Without weeding do not expect any harvest. The back has to ache to conquer the weeds" can tell us a great deal about how smallholders view the critical need for more and better access to farm mechanization [22].

In summary, farm power and mechanization is an essential input into smallholder agriculture to raise labor and land productivity, not just in agricultural production but along the value chain; improve timeliness of agricultural operations; reduce drudgery and alleviate the load on women, the elderly and children. Table 2 summarizes the impacts of mechanization on smallholder livelihoods and gives references for further examination of the issues.

\subsection{Increasing Demand for Mechanization}

Smallholder farmers tend to be, generally speaking, resource-poor with correspondingly low incomes. This means that they tend to put pressure on natural resources (resulting in their consequent degradation) and it also means that their levels of savings are low. Low levels of disposable income will mean that demand for farm power and mechanization inputs will be low and so land and labor productivity remain at low levels. So there is a continuing cycle of poverty from which is difficult to escape [23]. There is also a parallel cycle of pressure on natural resources (especially soil and water), which leads to the same unfortunate end, increased poverty [24]. If demand for mechanization inputs can be increased then a more positive cycle of events will take place. The resulting improved productivity will raise levels of savings, which in turn will lead to greater demand for productivity enhancing inputs, including mechanization. These will lead to greater productivity and so the self-reinforcing cycle continues. However, there are further advantages that accrue as higher demand for mechanization will lead to an increase in supply which will permit lower per-unit costs for services and so increase demand-a second self-reinforcing virtuous cycle. The challenge is to get 
sustainable mechanization available to farmers so that the poverty cycle can be broken and improved livelihoods ensue.

Table 2. Examples of the positive impacts of mechanization on smallholder livelihoods.

\begin{tabular}{llll}
\hline Factor Affected by Mechanization & \multicolumn{1}{c}{ Potential Improvement } & References \\
\hline Labor productivity & Farm family can cultivate 1-2 ha by hand; $>2$ ha with DAP; $>8$ ha with tractor & {$[5-8,12-17]$} \\
\hline Land productivity & $\begin{array}{l}\text { Increased production through better placement of seed and fertilizer, better } \\
\text { weed control through line-planting and improved timeliness (see later) }\end{array}$ & [9-11,13,19] \\
\hline Value chain development & $\begin{array}{l}\text { Holistic improved mechanization along the value chain from producer to } \\
\text { consumer can greatly improve productivity and improve livelihoods }\end{array}$ & [18-21,25] \\
\hline Timeliness of operations & Approximately 1\% reduction of yield per day of delay in planting & $\begin{array}{l}\text { Reducing the need for women's muscle power, } \\
\text { especially hand-hoeing and transport }\end{array}$ \\
\hline Drudgery reduction & [6,10,14,18] & \\
\hline
\end{tabular}

\subsection{Mechanization along the Value Chain}

Mechanization is an essential input not only for crop production, but it also has a crucial role to play along the entire value chain $[25,26]$. By mechanizing the whole process of agricultural crop value addition from planting to marketing, higher value outputs can be produced, rural employment can be created and sustained, post-harvest losses can be reduced, quality can be enhanced and smallholders can be integrated into the market economy. Table 3 illustrates the concept of mechanization along the value chain.

We emphasize that it is always necessary to take a holistic view of the whole value chain in order not to create bottlenecks further along the line once one constraint is alleviated, there were many ideas for starchy root crops emanating from the Beijing sessions. Emmanuel Bobobee [27] presented work on cassava harvesting using a wide (approximately $1 \mathrm{~m}$ ) inclined blade attached to the tractor via its three-point linkage. This replaces arduous manual labor in Ghana and can lift a plant in $1 \mathrm{~s}$, compared to 5-10 min manually. Fadel Ndiame [28] discussed the whole cassava value chain where it becomes clear that crop storage and the production of high quality cassava flour, ethanol and starch follow the post-harvest operations of peeling, chipping, grating and drying to greatly enhance the value of the cassava crop. Of course sophisticated crop processing of this nature is beyond the means of individual smallholder producers, but well within the means, with the appropriate technical support, of groups organized into cooperative processing companies.

Table 3. The potential for mechanization along the agricultural production value chain.

\begin{tabular}{llll}
\hline \multicolumn{1}{c}{ Production } & Post-harvest/storage & Processing & Marketing \\
\hline $\begin{array}{l}\text { Crop establishment Weeding } \\
\text { Fertilization Irrigation Crop } \\
\text { protection Harvesting }\end{array}$ & $\begin{array}{l}\text { Drying Grading Winnowing } \\
\text { Cleaning Storage }\end{array}$ & $\begin{array}{l}\text { Chopping Milling } \\
\text { Grinding Pressing }\end{array}$ & PackagingTransport \\
\hline
\end{tabular}

\subsection{Spreading the Risk}

Fadel Ndiame [29] takes up the need for a value chain approach and adds the context of riskiness along the chain. As can be seen in Table 4, the value of produce increases along the chain and also the level of risk involved is variable, peaking during the crop production mechanization "eco-system". This helps to explain why financial services aimed at mechanizing smallholder crop production are frequently difficult to encounter, or are too expensive for the intended clientele. Put simply, the risk, due to biological and weather variability and stresses, is too high. 
Table 4. Product value and risk levels along the agricultural produce value chain.

\begin{tabular}{ccccc}
\hline Mechanization "Ecosystem" & Input Supplies & Crop Production & Harvesting & Post-Harvest Processing \\
\hline Product value & \\
Risk involved & \\
\end{tabular}

Source: After Ndiame. [29].

The implications of the situation depicted in Table 4 are that mechanization inputs for the high-risk crop production ecosystem require particular arrangements that lower the risk for individual smallholders. These arrangements require an integrated approach (covering seed, fertilizer, irrigation and sustainable agricultural practices) and could involve cooperative ownership of farm machinery or specialist service providers-concepts that will be discussed in later sections.

\section{Sustainable Agricultural Production}

In Africa the Green Revolution has not had the same impact as it did in Asia. Investment in tractors, fertilizer use and use of other modern technologies have remained low throughout most of the continent to date (Table 5).

Table 5. Tractor populations in different regions from 1961 (millions of units).

\begin{tabular}{cccc}
\hline Region & $\mathbf{1 9 6 1}$ & $\mathbf{1 9 7 0}$ & $\mathbf{2 0 0 0}$ \\
\hline Sub-Saharan Africa & 0.172 & 0.275 & 0.221 \\
Asia & 0.12 & 0.6 & 6 \\
Near East & 0.126 & 0.26 & 1.7 \\
Latin America & 0.838 & 0.637 & 1.8 \\
\hline
\end{tabular}

Source: Breuer et al. [25].

Table 5 shows that in SSA the number of tractors actually declined between 1970 and 2000 and the fact is that manual labor is still the norm for $65 \%$ of farmers in SSA. Land degradation is a major problem in Africa, very frequently as a result of the formation of hoe-or plow-pans [30]. Africa needs to mechanize its agriculture and this should be accomplished in accordance with the principles of SCPI that FAO has detailed in its "Save and Grow" guidelines [31], which have conservation agriculture (CA) at their heart [32].

\section{What Mechanization is Appropriate?}

\subsection{Range of Power Sources}

The type and level of mechanization that may be appropriate is usually a situation-specific judgment. The most suitable option will come from the range of power options available-manual, draft animal and motorized - and all three power sources may be found to be appropriate in a given situation. For example, a tractor-drawn direct drill operator in Brazil will often carry a manual jab-planter (matraca) in the tractor cab to be able to quickly and effectively sow awkward corners in the field. A rice farmer in China may manually handle sheaves of crop, reaped by two-wheel tractor ( $2 \mathrm{WT}$ ) power, and transport them to the threshing site using animal drawn carts. Other examples are given by Van Loon et al. [33] who explain that, in Mexico, the northern states are dominated by large farms with advanced machinery and irrigation systems. Moving southwards there is a range of farming types using hand tools, draft animals and small four-wheel tractors (4 WTs). They suggest 
that mechanization should not be seen as a progression from hand to draft animal to tractor power. Rather there is a mosaic of power sources and emphasis should be placed on mechanizing activities, such as timely crop establishment, that are critical for productivity enhancement, and for reducing the drudgery load, an especially important point for rural women.

\subsection{Selection from a Range of Options}

The mechanization options available to smallholder farmers should not be controlled in a top-down way. Instead the views and opinions of all relevant stakeholders should be taken into account. The stakeholders will include farmers, manufacturers, machinery dealers, academia, extension services and policy makers. This topic is developed further in Section 6 where it is made clear that mechanization as a result of (often) politically motivated gestures is unlikely to result in sustainable solutions as ancillary equipment, service back-up and the supply of replacement parts are all likely to be inadequate. The private sector must be involved in the supply of appropriate mechanization options and the stakeholders in the mechanization input supply and servicing chains must be able to make a living from their activities.

The aim should usually be to offer a choice of options and help, if necessary, farmers to select the alternative best suited to their conditions. When discussing agricultural mechanization strategies, FAO [23] suggests that their purpose is to create an enabling policy framework, as well as an institutional and market environment, in which farmers and other end-users (such as service providers) have as wide a choice as possible of farm power and equipment suited to their needs within a sustainable delivery support system.

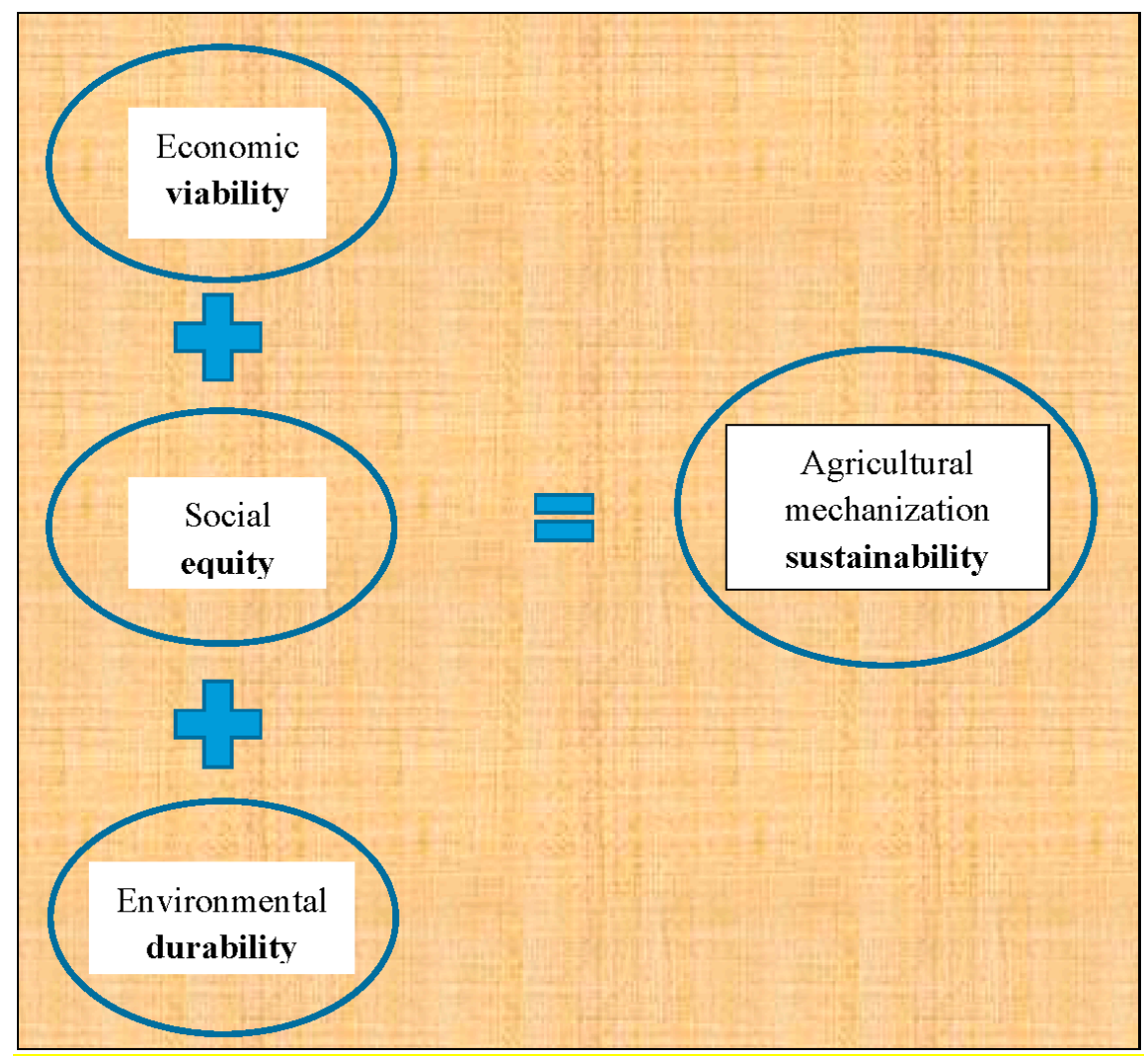

Figure 1. Agricultural mechanization—the principles of sustainability (source: after FAO [23]).

\subsection{Sustainable Mechanization}

Smallholder farm mechanization must be a sustainable pursuit. Short-term gains which don't adequately take the longer term implications into account and do not build-in sustainable longevity, 
will not produce useful and enduring results. There are two aspects to this: one is the economic and social sustainability; and the other is environmental stability as discussed in Section 3. FAO [23] reminds us that mechanization is an investment for farmers and they have to generate income and profit from their investment by means of greater production or increased value. The economic aspect also has to take into account the commercial and financial links between farmers and the other stakeholders; for the sector to be sustainable, there need to be strong linkages between the stakeholders and as previously emphasized, they must all be able to make their livelihoods from their businesses. There may also be social aspects to be considered, but these may be intangible or at least difficult to quantify in financial terms. A reduction in drudgery and an increase in leisure time could fall into this category, although drudgery reduction could also be considered as a productivity-enhancing action. The enhancement of a machinery owner's status in the community may also be an important factor. Figure 1 brings these factors together and depicts them as being conducive to sustainable agricultural mechanization.

\section{Local Manufacture}

One of the most important messages to bear in mind is that collaboration is key to the success of the development of the private sector agricultural machinery manufacturing sector in SSA. Figure 2 shows how manufacturers are intimately reliant on other stakeholders in the machinery supply chain.

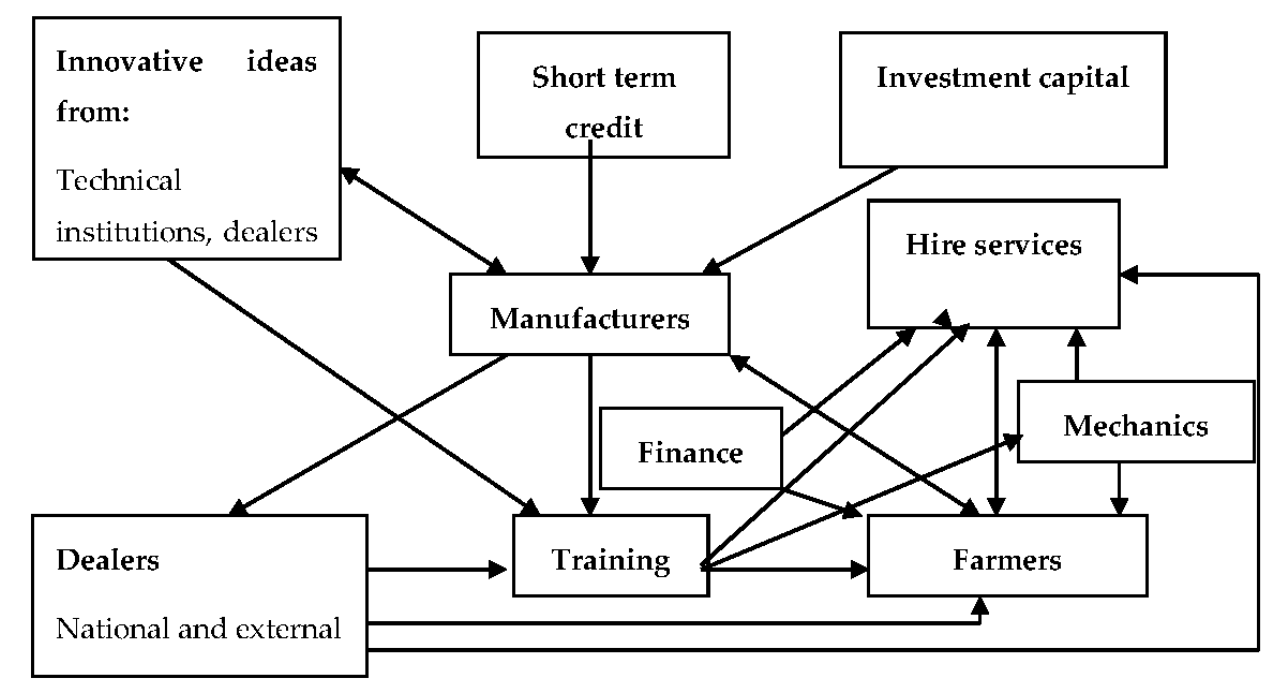

Figure 2. Machinery supply chain for farm machinery manufacturers (source: Sims et al. [34]).

Sims et al. [34] discuss useful guidelines for the development of the machinery manufacturing industry in SSA.

The clear message from Tanzanian commercial manufacturer Peter Chisawillo [35] was that innovation was vital and that collaboration is essential to achieve continuous innovation. Each of his successful lines of machinery has been the result of extensive collaboration between national and international stakeholders and takes into account farmer demand and ability to invest. It is hard work and, as Thomas Edison famously commented in 1877: "genius [innovation] is 1\% inspiration and 99\% perspiration". There is no short track to manufacturing agricultural machinery suitable for, and adopted by, the smallholder farming community and their service providers.

\section{Roles of the Public and Private Sectors}

Much has been said of the demise of public sector mechanization schemes widely promoted in many SSA countries in the second half of the 20th Century. Rural mechanization services, or tractor hire schemes, were well-intentioned efforts to make tractor-powered agricultural mechanization available 
to smallholder farmers. However the services were effectively a government subsidy and the financial burden was all too easy to shed when government priorities shifted. The schemes were typically overburdened with a bureaucratic hierarchy, which found it difficult to adapt to the seasonal nature of agricultural operations, such that timeliness, so essential for yield optimization, suffered, leaving farmer clients dissatisfied with the service. Other problems included: long travelling distances between clients' farms; poor rural road infrastructure; erratic supplies of clean fuel; availability of replacement parts; and effective maintenance and repair facilities (Figure 3). Studies of the financial sustainability of public-sector run mechanization services have shown that their viability is generally questionable and they were largely abandoned by the turn of the century [36].

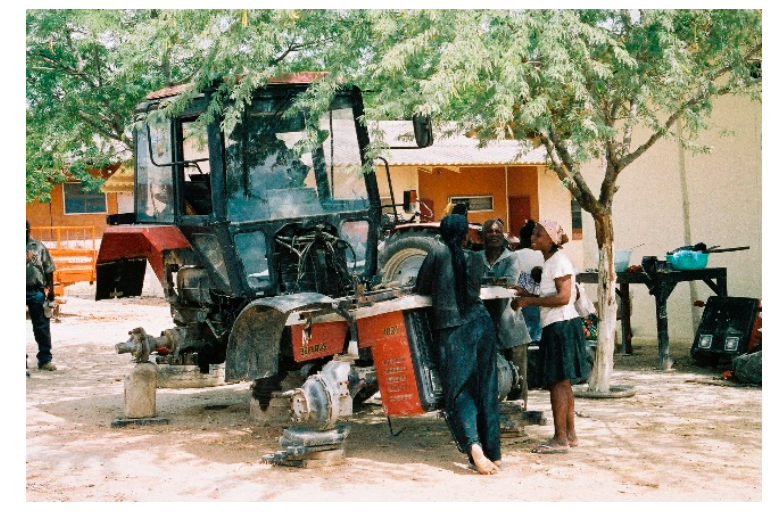

Figure 3. Public sector run machinery hire services face an insurmountable number of technical and administrative obstacles, which make them financially non-viable. (Photo: Brian Sims).

The lesson to be learnt is that the public sector should facilitate mechanization for smallholder farmers, not attempt to supply it, however politically attractive that may seem in the short term. Conversely, the private sector should be empowered to supply the mechanization demanded by smallholders through commercial supply chains. This will ensure that the supply of mechanization services will be sustainable and not be subject to the vagaries of political and economic climates, as only viable business models will survive.

However, there are ways in which the public sector can play an important supporting role, and these include:

- Promulgating enabling policies such as reduced taxes and import duties on agricultural machinery. Improvement of rural infrastructure will also play a major facilitating role. Singh [37] explains that an important factor in increasing agricultural mechanization in India was the government's concerted effort to popularize tractors and make them more affordable to more farmers-reducing excise duty in the 1980s was but one way to achieve this goal.

- $\quad$ Building technical and business management skills through targeted and focused training programs.

- Offering financial incentives to stimulate demand. This could be through the offer of preferential interest rates on loans for agricultural machinery purchase. Other ways to stimulate demand for private sector mechanization services include issuing e-vouchers for mechanization services to the least well-off sectors of the smallholder community.

Government support will often be needed to kick-start the mechanization process, but the emphasis should always be on the demand side with the public sector being involved in the ways described above, and especially in the supply of affordable credit for agricultural machinery purchase. Top-down planning (for example, achieving a certain level of $\mathrm{kW} /$ ha in a particular time frame) is unlikely to be the answer; focusing on empowering the private sector business will create jobs amongst the various stakeholders in the supply and value chains. 
Public sector interventions to assist smallholder farmers in gaining access to mechanization services are discussed by FAO [38].

\section{Making Mechanization Accessible}

\subsection{Lessons from China}

Smallholder Development

China, with a third of the world's population of smallholder farmers (with, typically, $1 / 8$ ha of land per family) needs public sector support to sustain and develop its agricultural sector. Public sector assistance is provided in the form of financial incentives and subsidies. In addition there is a strong local manufacturing capacity so solid technical backup is readily available for smallholder farm mechanization.

The Chinese government offers a 30\% subsidy for the purchase of agricultural machinery. There are also substantial subsidies for other inputs including seeds, fuel, agrochemicals and plastic mulch [39]. The government also applies production subsidies to raise smallholder farm family incomes. For example, the grain minimum support price costs USD 2.2 billion a year. Extension services are strong and include advice on cropping systems advances, in parallel with increased mechanization. Plot consolidation is encouraged to ease mechanization. Rural-urban migration permits sale of land and larger scale properties are emerging; mechanization benefits the women, elderly and children who tend to be left behind to care for the family farm. Freer movement and the ability to buy and sell land has been made possible by a liberalization of markets and a trend away from communal forms of farming to empowering individual farmers to make their own decisions since the $1990 \mathrm{~s}$ [39]. Information technology is increasingly used to modernize farming systems and to facilitate an internet-based extension service [40]. The levels of the agricultural extension service cascade from national to provincial to municipal to county and, finally to township level [41].

Infrastructure development (especially for transport but also of utilities) is key to encouraging agricultural development. As Fang [39] says: "if you want to get rich [as a nation] build roads first".

\subsection{China's Agricultural Machinery Industry}

China is one of the world's largest manufacturers of agricultural machinery, currently experiencing a 20\% annual growth rate and an increasing export volume, which reached USD 10 billion in 2014 [42]. Costs are kept to a minimum and currently tractors are being produced for a price of USD 157/hp (USD $210 / \mathrm{kW}$ ). Small capacity combines can be manufactured for USD 15,000 and currently 150,000 units are produced annually. Chinese manufacturers are aware of the need to reform traditional production methods to improve product quality, and emphasis is being put on this aspect to improve their international image.

The Chinese-Africa Machinery Corporation (YTO) has a focus on the transfer of technology in the interests of smallholder farm development in Africa. Hao [43] emphasizes the problem of finance acquisition in Africa and considers that lack of funding for the sector is the first obstacle to be overcome. There is a clear role for the public sector here. Further priorities are training in machine operation and maintenance and assuring a ready supply of spare parts.

The approach to the African market needs to bear in mind the following points:

- Machinery must be easy to maintain and operate. Ideally, operation should be intuitive.

- Tractor engines should incorporate a minimum of electric components. Simple diesel engines are preferred for their simplicity, low price, good torque characteristics and safer fuel storage.

- Service networks close to users need to be put in place (a suggested minimum is for 20 service centers per country).

- Training at multiple levels is a fundamental component of successful marketing. 


\subsection{Equipment}

The 2 WT (6-12 hp) has been a widely adopted technology, relieving drudgery and taking farm power away from human muscle and animal-powered agriculture [39]. Chinese manufacturers displayed examples of the wide range of attachments available for 2 WTs at the B\&MGF meeting in Beijing and Figures 4-7 give a flavor of the versatility available to Chinese smallholder farmers. Throughout the display, equipment suitable for sustainable conservation agriculture was conspicuous by its scarcity.

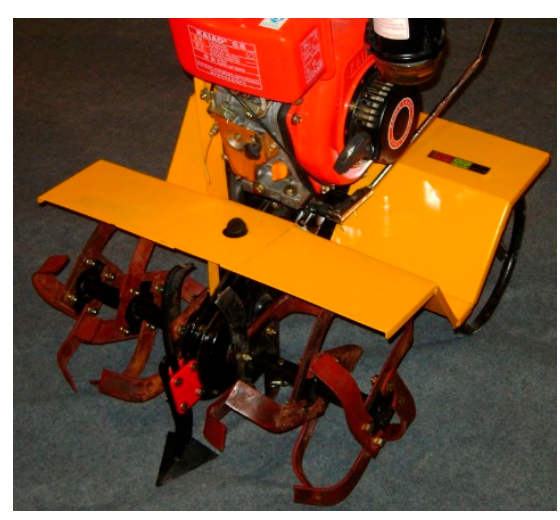

Figure 4. Datang 2 WT with rotary cultivator. (Photo: Brian Sims).

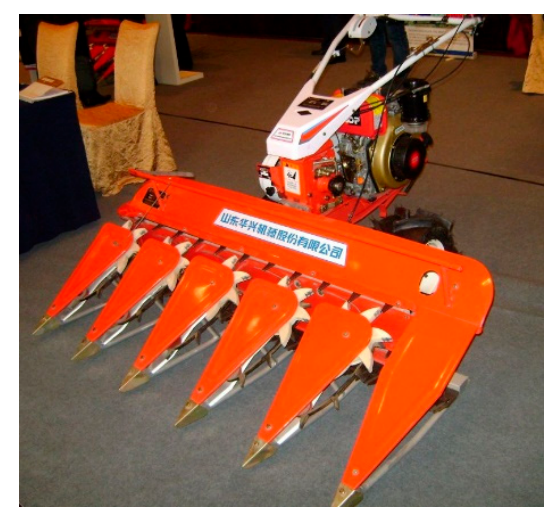

Figure 5. Huaxing cereal harvester mounted on a 4 kW (5.4 hp) 2 WT. (Photo: Brian Sims).

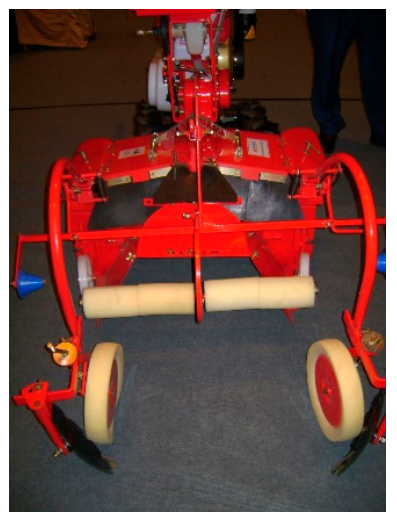

Figure 6. Huaxing plastic mulch-laying machine. The tractor forms the $1 \mathrm{~m}$-wide ridge before applying the mulching film (Photo: Brian Sims). 


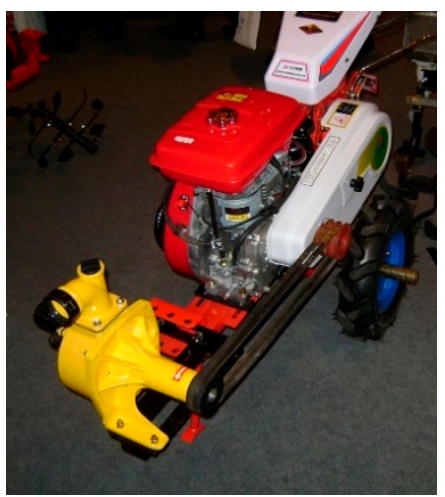

Figure 7. Huaxing 2 WT driving a water pump for crop irrigation (Photo: Brian Sims).

There is now a move to a preference for $4 \mathrm{WTs}(12-18 \mathrm{hp})$, which provide greater versatility, safety and ease of operation. They can also be equipped with a more diverse range of implements. Fang [39] gives an indication of the rate of decline of draft animal power and the rate of adoption of small 4 WTs and motorized farm-vehicle power in China. Draft animal numbers have declined from a peak of 80 million in 1997 to 35 million by 2010. Low-power tractor numbers have remained fairly constant at 30 million units over the same period, but three-and four-wheeled farm transport vehicles have soared to 80 million. In the same way that $4 \mathrm{WTs}$ are emerging as the predominant power source, so combine harvesters are replacing the reaper + thresher + cleaner associated with the 2 WT systems. Combine harvester adoption has followed the typical sigmoid adoption curve from zero in 1978 to 1.4 million in 2014. At the same time, grain thresher adoption rose to over 10 million in 2012 before starting to fall.

Figures 8-12 show some of the 4 WT equipment on display at the Beijing meeting, some of it requiring tractors of up to $30 \mathrm{hp}$. Figure 13 shows a crawler-mounted crop sprayer for tree crops suitable for contract work on smallholder farms.

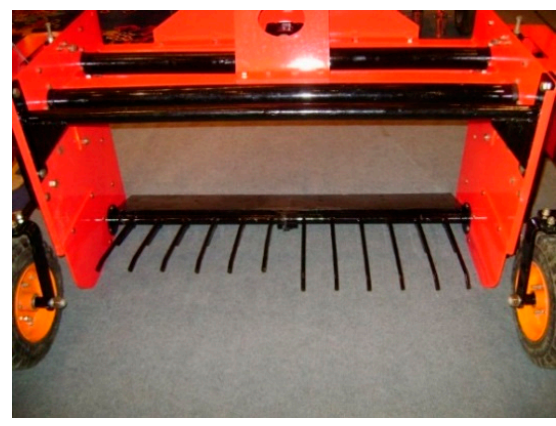

Figure 8. MAEC (Modern Agricultural Equipment Co. Ltd) sweet potato lifter (Photo: Brian Sims).

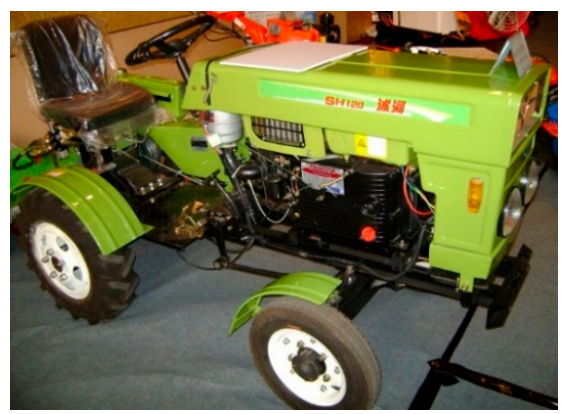

Figure 9. SH (Shandong) $11 \mathrm{~kW} 4 \mathrm{WT}$ (Photo: Brian Sims). 


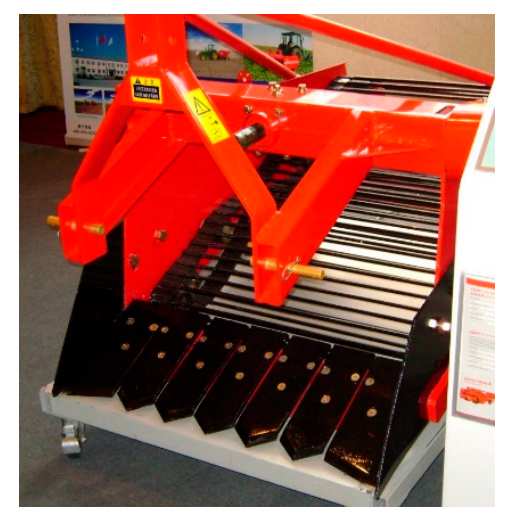

Figure 10. Menoble 3-point linkage mounted single row potato harvester for a $30 \mathrm{hp}$ tractor (Photo: Brian Sims).

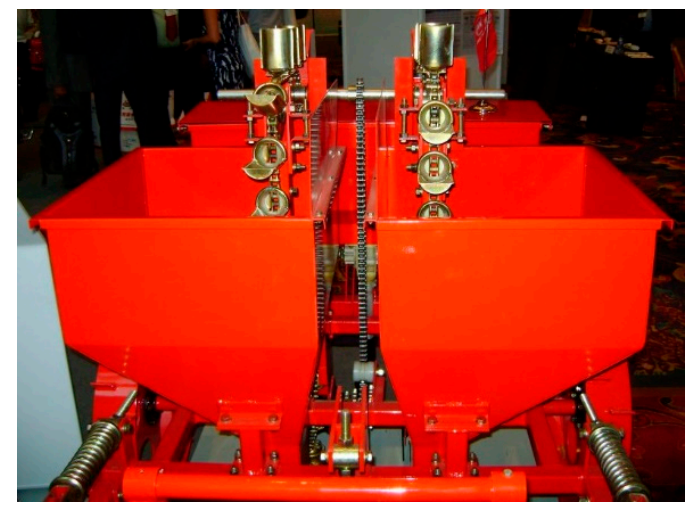

Figure 11. Menoble 3-point mounted 2-row potato planter (Photo: Brian Sims).

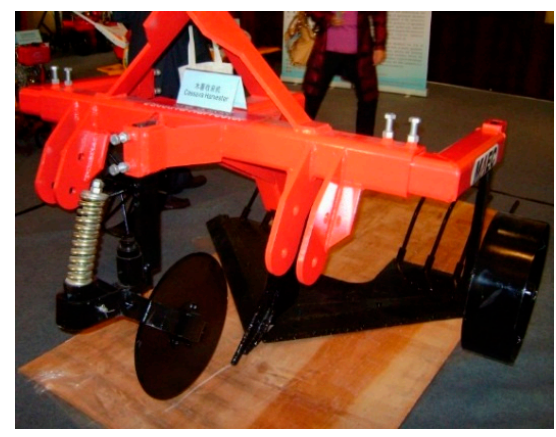

Figure 12. MAEC cassava lifter (Photo: Brian Sims).

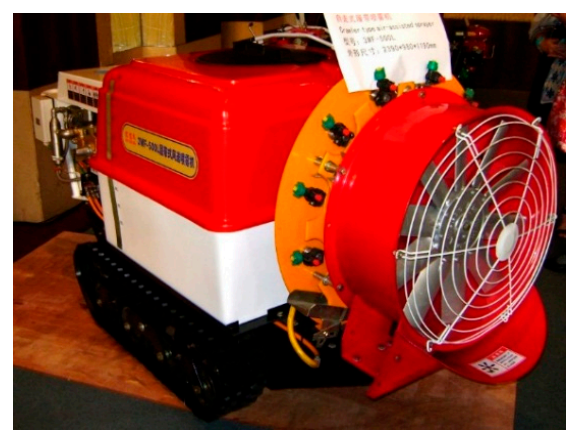

Figure 13. Datang hand-operated, or remote-controlled, fan sprayer for tree crops (Photo: Brian Sims). 


\subsection{Delivering Mechanization Services to Smallholder Farmers}

The ways that the private sector can become involved in the supply of mechanization services to smallholder farmers include:

- Group ownership, whereby several neighboring farmers can unite to form a group that can then invest in agricultural machinery for the use of all members. Groups (as opposed to individual farmers) will often gain easier access to credit on more favorable terms, but there are recurrent problems associated with this type of arrangement. Firstly, there is the problem of timeliness-all members will probably require the same machine at the same time. Then, there are the questions of who will operate the machine; who is responsible for maintenance and repairs; and how is that to be funded? However, the model can work in situations where there is mutual respect and confidence.

- Service provision by an owner of agricultural machinery. This could be a farmer who attends to his own needs first and then supplies services to neighbors; or it could be a full-time service provider.

These models, and variations of them were discussed by Baudron [44] at the meeting and are expanded in [14] and [45]. In his presentation, Baudron drew out some lessons for service provision from experience gained to date:

- Service provision makes sense, as few farmers will be able to purchase machines individually. In addition, it will generally not be profitable for smallholder farmers to own machines unless they provide services.

- A service provider will probably need to generate an income throughout the year and this will mean offering a range of services for different seasons such as crop establishment, weeding, crop care, harvesting and post-harvest operations, and some that are not seasonal such as transport. In other words providers need to link the need for inputs into crop production with processing the output of crop production enterprises.

\section{A Center for Sustainable Agricultural Mechanization for Africa}

Asia's Center for Sustainable Agricultural Mechanization (CSAM) is a regional institution of the United Nations' Economic and Social Commission for Asia and the Pacific (UNESCAP) based in Beijing. It started operations in 2004, building on the achievements of its forerunner, the Regional Network for Agricultural Machinery (RNAM) [46]. A CSAM for Africa (CSAM-A) could play an important role in lifting the continent's smallholder farmers out of their cycle of drudgery and low productivity and the following is a summary of the CSAM ambitions and achievements.

Zhao [47] gives an overview of CSAM and its relevance to improving smallholder access to mechanization services. CSAM is essentially a regional forum with a vision to achieve productivity gains, improved rural livelihoods and poverty alleviation through sustainable agricultural mechanization. The objective of CSAM is to enhance technical cooperation amongst ESCAP members and serves as a data and information hub to facilitate information exchange, knowledge sharing and R\&D in sustainable agricultural mechanization. CSAM also serves as a reference point for standards and protocols; a center for capacity building; and a facilitator for intra-regional agri-business development and trade.

Mrema et al. [48] observe that, with increased awareness of the need for environmental protection and adaptation to (and mitigation of) climate change, the paradigm of sustainable production intensification (SPI) is being actively promoted in the Asia and Pacific region. They advocate the formulation and implementation of sustainable agricultural mechanization strategies (SAMS) as part of an enabling environment for the development of sustainable agri-food chains in parallel with the enhancement of the natural resource base. Inappropriate mechanization can lead to increased pressure on fragile agro-ecosystems by accelerating soil erosion and compaction, promoting forest and 
rangeland destruction and encouraging the over-use of chemical inputs. There is currently a global movement towards reducing tillage and moving towards CA.

A SAMS must take cognizance of the predominance of smallholders in the region and seek to improve their access to machinery inputs such as tractors, combines and stationary motors. This can be achieved through the provision of private sector custom hiring services, but will also require the provision of an enabling financial and infrastructural environment. Mrema et al. [48] emphasize the importance of the private sector for the delivery of sustainable mechanization; the public sector's role should be confined to incubating and enabling and should not be tempted to provide mechanization services. Increased R\&D investment in both the private and public sectors is required as the SPI paradigm is not yet mainstream. The authors believe that the CSAM will play a pivotal role in building capacity for SAMS implementation. Capacity building must focus on the youth and integrate considerations of, inter alia, natural resource protection and gender issues.

CSAM's strategy for promoting smallholder farm mechanization includes encouraging the development of custom hire services [47]. This will include the development of information and communications technology (especially based on mobile phones) accompanied by services of market information, training and access to credit and other inputs. Developing risk management strategies is also a priority for the sector.

One clear example of how a CSAM for Africa could operate to remove constraints along the production chain was provided by Felix Nweke from Nigeria [49]. He explained that constraints (bottlenecks) can be identified and alleviated, through investment and investigation, but this gives rise to further challenges as yields and production intensification increase. Traditional cassava production in Nigeria was constrained by pests and diseases, which were overcome by the advent of resistant high-yielding varieties. Improved yields then met with the bottleneck of labor for processing which was broken with the design and application of mechanical processing machines. Further yield increases created a harvesting bottleneck, which was alleviated by mechanized harvesting technologies. New constraints are expected as yields and production methods continue to improve and the yield potential for cassava has yet to be realized.

\section{Conclusions and Recommendations}

Smallholder farmers need farm power and mechanization to raise the productivity of their land and labor and to see improvements in farm family livelihoods. This essential input is not only needed for agricultural production, but along the value chain for farm produce. Mechanization is needed to alleviate drudgery and to alleviate the load on women, children and the elderly, all of which equates to an increase in labor productivity.

In order to feed the increasing world population with finite (and currently degrading) natural resources, it is vital that sustainable mechanization options are employed. This means increasing food production whilst conserving soil and water-sustainable crop production intensification-and calls for the practices of conservation agriculture to be vastly scaled up and out.

There is a wide range of appropriate mechanization options suited to smallholder farming conditions. All power sources (manual, draft animal and motorized) can be appropriate. The important point is to make the options available by involving all stakeholders in the mechanization input chain. This means including farmers, manufacturers, dealers, academia and policy makers. The private sector must be the main supplier of mechanization inputs to ensure sustainability of supply and service into the future.

Although mechanization options can come from a variety of sources, local manufacture can offer some advantages. Local manufacture tends to focus more closely on local need and issues and so can often more perfectly address farmers' needs. Locally produced equipment is also more likely to be supported by a constant supply of spare parts and service backup.

The public sector should only be involved in facilitating the supply of mechanization inputs from the private sector. Public sector machinery hire services are likely to be unreliable and uneconomic; 
and public sector activities in supplying imported machinery usually result in poor service support and the alienation of private sector suppliers.

Improving smallholders' access to farm power and machinery inputs is crucial as machinery purchase is often beyond the means of a large proportion of the sector. Group ownership is a possibility and can be supported by public sector incentives. Private sector custom mechanization services are probably the most appropriate vehicle and should be supported by public sector incentives and training.

Africa would benefit from at least one regional center for sustainable agricultural mechanization, based on UNESCAP's CSAM model in Beijing, China.

Acknowledgments: We gratefully acknowledge the support from the Bill and Melinda Gates Foundation to enable our participation in the Grand Challenges meeting in Beijing.

Author Contributions: Both co-authors contributed equally to all phases of the elaboration of the paper.

Conflicts of Interest: The authors declare no conflict of interest.

\section{References}

1. Sustainable Development Knowledge Platform: Sustainable Development Goals. Available online: https://sustainabledevelopment.un.org/topics (accessed on 12 April 2016).

2. Sims, B.G.; Kienzle, J.; Hilmi, M. Agricultural Mechanization: A Key Input for Sub-Saharan African Smallholders; Food and Agriculture Organization of the United Nations: Rome, Italy, 2016; in press.

3. Sims, B.G.; Kienzle, J. Rural mechanisation: Where are we now and where should we be going? Rural 21 2015, 21, 6-9.

4. Agarwal, B. Agricultural Mechanisation and Labour Use: A Disaggregated Approach. Int. Lab. Rev. 1981, 120, 115-127.

5. Bishop-Sambrook, C. Contribution of Farm Power to Smallholder Livelihoods in Sub-Saharan Africa; Food and Agriculture Organization of the United Nations: Rome, Italy, 2005; p. 87.

6. Van Eerdewijk, A.; Danielsen, K. Gender Matters in Farm Power. Available online: https://www. researchgate.net/publication/282976045_Gender_Matters_in_Farm_Power (accessed on 12 April 2016).

7. Giles, G.W. The Reorientation of Agricultural Mechanization for the Developing Countries. In FAO Report on Effect of Farm Mechanization on Production and Employment; Food and Agricultural Organization (FAO): Rome, Italy, 1975.

8. Reid, J.F. The Impact of Mechanization on Agriculture. In The Bridge; National Academy of Engineering: Washington, DC, USA, 2011; Volume 44, pp. 22-29.

9. Singh, G. Estimation of a mechanisation index and its impact on production and economic factors-A case study in India. Biosyst. Eng. 2006, 93, 99-106. [CrossRef]

10. Verma, S.R. Impact of Agricultural Mechanization on Production, Productivity, Cropping Intensity Income Generation and Employment of Labour; Punjab Agricultural University: Ludhiana, India, 2006.

11. Faleye, T.; Adebija, J.A.; Farounbi, A.J. Improving small-farm productivity through appropriate machinery in Nigeria. Int. Res. J. Agric. Sci. Soil Sci. 2012, 2, 386-389.

12. FAO \& World Bank. The Kyrgyz Republic: Farm. Mechanization and Agricultural Productivity; FAO Investment Centre; Food and Agriculture Organization of the United Nations: Rome, Italy, 2009; p. 74.

13. Food and Agriculture Organization of the United Nations. Farm. Power and Mechanization for Small Farms in Sub-Saharan Africa; Agricultural and Food Engineering Technical Report 3; Sims, B.G., Kienzle, J., Eds.; FAO: Rome, Italy, 2006; p. 67.

14. Baudron, F.; Sims, B.; Justice, S.; Kahan, D.; Rose, R.; Mkomwa, S.; Kaumbutho, P.; Sariah, J.; Nazare, R.; Moges, G.; et al. Re-examining appropriate mechanization in eastern and southern Africa: Two-wheel tractors, conservation agriculture, and private sector involvement. Food Secur. 2015, 7, 889-904. [CrossRef]

15. Barton, D.; Okuni, A.; Agobe, F.; Kokoi, R. The Impact of Ox-Weeding on Labour Use, Labour Costs and Returns in the Teso Farming System. In Proceedings of the International Workshop on Modernizing Agriculture, Visions and Technologies for Animal Traction, Jinja, Uganda, 19-25 May 2002. 
16. Mrema, G.C.; Baker, D.; Kahan, D. Agricultural Mechanization in Sub-Saharan Africa: Time for a New Look; Agricultural Management, Marketing and Finance Occasional Paper 22; Food and Agriculture Organization of the United Nations: Rome, Italy, 2008; p. 54.

17. FAO. Investment in Agricultural Mechanization in Africa. Conclusions and Recommendations of a Round Table Meeting of Experts; Agricultural and Food Engineering Technical Report 8; Ashburner, J.E., Kienzle, J., Eds.; Food and Agriculture Organization of the United Nations: Rome, Italy, 2011; p. 76.

18. FAO. Addressing the challenges facing agricultural mechanization input supply and farm product processing. In Proceedings of an FAO Workshop Held at the CIGR Congress on Agricultural Engineering, Bonn, Germany, 5-6 September 2006.

19. Yaregal, E. Experience of rice value chain project in Anhara region. In Experience in Rice Mechanization; Shiratori, K., Alemu, D., Kelemu, F., Eds.; Ethiopian Institute of Agricultural Research: Addis Ababa, Ethiopia, 2014; pp. 1-16.

20. Food and Agriculture Organization of the United Nations. Farm Equipment Supply Chains; FAO: Rome, Italy, 2009; p. 48.

21. Hilmi, M. Hire services as a business: The potential for developing business enterprises with tractors, machinery and draught animals. Agric. Dev. 2013, 19, 21-24.

22. International Fund for Agricultural Development (IFAD); Japan Official Development Assistance (Japan ODA); Food and Agriculture Organization of the United Nations (FAO). Agricultural Implements Used by Women Farmers in Africa; International Fund for Agricultural Development, Japan Official Development Assistance, Food and Agriculture Organization of the United Nations: Rome, Italy, 1998; p. 129.

23. Food and Agriculture Organization of the United Nations. Agricultural Mechanization in Sub-Saharan Africa: Guidelines for Preparing a Strategy; FAO: Rome, Italy, 2013.

24. Twomlow, S.; O’Neill, D.; Sims, B.; Ellis-Jones, J.; Jafry, T. An engineering perspective on sustainable smallholder farming in developing countries. Biosyst. Eng. 2002, 81, 355-362. [CrossRef]

25. Breuer, T.; Brenneis, K.; Fortenbacher, D. Mechanisation-A catalyst for rural development in sub-Saharan Africa. Rural 21 2015, 49, 16-19.

26. FAO. Addressing the Challenges Facing Agricultural Mechanization Input Supply and Farm Product Processing; Agricultural and Food Engineering Technical Report 5; Sims, B.G., Kienzle, J., Cuevas, R., Wall, G., Eds.; Food and Agriculture Organization of the United Nations: Rome, Italy, 2007; p. 71.

27. Bobobee, E.Y.H. Development, evaluation and promotion of mechanical cassava harvesting technology for root and tuber crops production in Africa. In Proceedings of the Bill and Melinda Gates Foundation Grand Challenges Annual Meeting, Beijing, China, 18-21 October 2015.

28. Ndiame, F. Delivery of effective agricultural mechanization services to smallholder farmers. In Proceedings of the Bill and Melinda Gates Foundation Grand Challenges Annual Meeting, Beijing, China, 18-21 October 2015.

29. Ndiame, F. Mainstreaming mechanization in smallholder agriculture in Ghana: A development partner's perspective. In Proceedings of the Bill and Melinda Gates Foundation Grand Challenges Annual Meeting, Beijing, China, 18-21 October 2015.

30. Kienzle, J.; Sims, B.G. Strategies for a sustainable intensification of agricultural production in Africa. In Proceedings of the Open meeting of the Club of Bologna, Milan, Italy, 21 September 2015; p. 14.

31. FAO. Save and grow. In A Policymaker's Guide to the Sustainable Intensification of Smallholder Crop. Production; Food and Agriculture Organization of the United Nations: Rome, Italy, 2011; p. 102.

32. FAO. Conservation Agriculture. Available online: http://www.fao.org/ag/ca/ (accessed on 12 April 2016).

33. Van loon, J.; Baudron, F.; Krupnik, T. A round tour of mechanisation. Rural 21 2015, 49, 10-13.

34. Sims, B.G.; Thierfelder, C.; Kienzle, J.; Friedrich, T.; Kassam, A. Development of the conservation agriculture equipment industry in Sub-Saharan Africa. Appl. Eng. Agric. 2012, 28, 813-823. [CrossRef]

35. Chisawillo, P. Institutional collaboration in promoting mechanization for smallholder farmers. In Proceedings of the Bill and Melinda Gates Foundation Grand Challenges Annual Meeting, Beijing, China, 18-21 October 2015.

36. Hatibu, N. Investing in agricultural mechanization for development in East Africa. In Mechanization for Rural Development: A Review of Patterns and Progress from around the World; Kienzle, J., Ashburner, J., Sims, B.G., Eds.; Food and Agriculture Organization of the United Nations: Rome, Italy, 2013; Volume 20, pp. 1-13. 
37. Singh, G. Agricultural mechanization in India. In Mechanization for Rural Development: A Review of Patterns and Progress from around the World; Kienzle, L., Ashburner, J., Sims, B.G., Eds.; Food and Agriculture Organization of the United Nations: Rome, Italy, 2013; Volume 20, pp. 99-119.

38. Kienzle, J.; Ashburner, J.; Sims, B.G. Mechanization for Rural Development: A Review of Patterns and Progress from around the World; Food and Agriculture Organization of the United Nations: Rome, Italy, 2013.

39. Fang, X. The emphasis of farming mechanization in its initial stage. In Proceedings of the Bill and Melinda Gates Foundation Grand Challenges Annual Meeting, Beijing, China, 18-21 October 2015.

40. Li, M. How to help smallholder famers with information technology. In Proceedings of the Bill and Melinda Gates Foundation Grand Challenges Annual Meeting, Beijing, China, 18-21 October 2015.

41. Yougou, R. Brief Introduction on Chinese agriculture and aggrotech extension in China. In Proceedings of the Bill and Melinda Gates Foundation Grand Challenges Annual Meeting, Beijing, China, 18-21 October 2015.

42. Gao, Y. China association of agricultural machinery manufacturers. In Proceedings of the Bill and Melinda Gates Foundation Grand Challenges Annual Meeting, Beijing, China, 18-21 October 2015.

43. Hao, Z. China-Africa Machinery Corporation-YTO. In Proceedings of the Bill and Melinda Gates Foundation Grand Challenges Annual Meeting, Beijing, China, 18-21 October 2015.

44. Baudron, F. Making mechanization accessible to smallholder farmers: Experience from CIMMYT and its partners. In Proceedings of the Bill and Melinda Gates Foundation Grand Challenges Annual Meeting, Beijing, China, 18-21 October 2015.

45. Sims, B.G.; Röttger, A.; Mkomwa, S. Hire Services by Farmers for Farmers; Rural Infrastructure and Agro-Industries Division; Food and Agriculture Organization of the United Nations: Rome, Italy, 2011; p. 82.

46. Center for Sustainable Agricultural Mechanization. Available online: www.un-csam.org (accessed on 12 April 2016).

47. Zhao, B. Overview of agricultural mechanization in Asia and the Pacific and custom hire strategies for smallholders. In Proceedings of the Bill and Melinda Gates Foundation Grand Challenges Annual Meeting, Beijing, China, 18-21 October 2015.

48. Mrema, G.; Soni, P.; Rolle, R. A Regional Strategy for Sustainable Agricultural Mechanization. In Sustainable Mechanization across Agri-Food Chains in Asia and the Pacific Region; Food and Agriculture Organization of the United Nations Regional Office for Asia and the Pacific: Bangkok, Thailand, 2014; p. 74.

49. Nweke, F. Mechanization of production: A necessary condition for cassava revolution in Nigeria. In Proceedings of the Bill and Melinda Gates Foundation Grand Challenges Annual Meeting, Beijing, China, 18-21 October 2015.

(C) 2016 by the authors; licensee MDPI, Basel, Switzerland. This article is an open access article distributed under the terms and conditions of the Creative Commons Attribution (CC-BY) license (http://creativecommons.org/licenses/by/4.0/). 